\title{
BIRD NOTES ON THE CYPRESS HILLS SUMMER MEETING
}

JIM A. WEDGWOOD (Compiler), 610 Leslie Ave., Saskatoon, Sask.

The Society held its 1976 Summer Meet at Cypress Hills Provincial Park from June 11 to 13. Notes on some of the more significant bird observations in the Cypress Hills district are presented. (A write-up on the activities and about the large turn-out of members and friends will no doubt appear in the Newsletter).

The notes were compiled from records kept by Wayne Harris and Sheila Lamont, Prince Albert, and Jim Wedgwood, Saskatoon. Ross Lein, Calgary, Frank Brazier and Lorne Scott, Regina, and Ole Nielsen, our President, also contributed. The observations were made on the scheduled field trips and also at other times during the weekend or while on our way to or from the Summer Meet. Except where otherwise stated, the notes pertain to the Centre and West Blocks and The Gap between them.

Eight birds were recorded whose breeding ranges are not shown by Godfrey in The Birds of Canada as including the Cypress Hills: Common Loon, Cooper's Hawk, Broad-winged Hawk, Yellow-bellied Sapsucker, Purple Martin, Ruby-crowned Kinglet, Tennessee Warbler and Western Tanager. Indications were that the buteo, kinglet and tanager were likely nesting - the first as evidenced by behaviour, the second by numbers and the third by nest building.

The Broad-winged Hawk was heard giving its territorial scream or was seen by three members at different times in the vicinity of the Valley of the Beavers Nature Trail in the southeast part of the Park with its pure and mixed stands of lodgepole pine, white spruce and poplar.

Ruby-crowned Kinglets were heard in three places, all in spruce woods, and two were heard beside Loch
Lomond, which is spruce and sprucepine fringed. Both Harris and I noted a slight difference between the typical song of these birds and that of the kinglets found in northern boreal forest. Harris wonders if they are a different subspecies.

I saw a male singing Western Tanager beside Lonepine Creek along the Valley of the Beavers Nature Trail where Lein later saw a pair with the female carrying nest material. Scott found a nest under construction by what may have been the same pair. Harris heard two singing males along the Trail. Lein saw another male at Fort Walsh, beside Battle Creek. Both locales were in spruce woods bordering the streams. Harris also saw and heard this species in the Terrace Campground. Thus a total of four and, possibly, five territorial males were recorded.

The other five species, not confirmed breeders in the Cypress Hills, were single observations. Harris heard a Common Loon on several occasions in the Loch Leven area, saw a female Cooper's Hawk circling over the north slope near Bald Butte, and saw a Yellow-bellied Sapsucker near Loch Leven. I saw a lone Purple Martin flying over the private cottage area. Harris saw a singing male Tennessee Warbler along Lonepine Creek.

I hope some day someone will take the time to prove out the breeding or otherwise of these species.

Some other notes of interest: Two groups of Society members returning from the field trip to Fort Walsh were treated to the sight of a pair of Turkey Vultures in courtship flight over The Gap near Six-mile Creek. Two adult Golden Eagles were also soaring in this vicinity. 


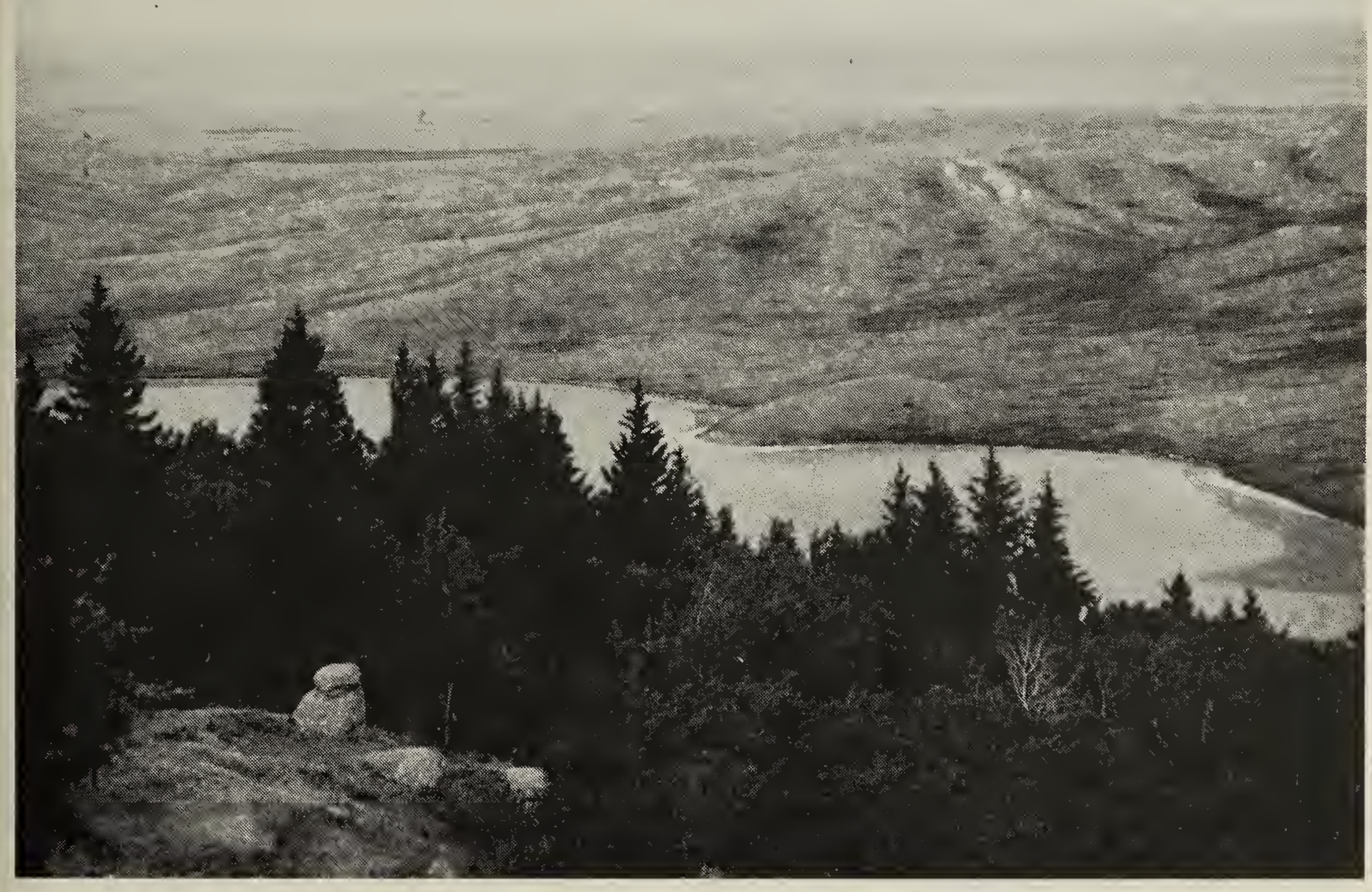

Adams Lake, Cypress Hills, Sask.

J. D. Hogg

For years a pair of the rare Trumpeter Swans have nested on Adams Lake at the foot of the conglomerate cliffs in the West Block. According to the Park Naturalist they were not nesting there this year, but rather on another lake nearby. However, on the Saturday Society groups saw a bird on Adams Lake and on the Sunday Nielsen and I saw two there. It could not be concluded they were nesting as both birds were on the water at the time.

Most Saskatchewan bird watchers consider the Dusky Flycatcher to be a rarity. Godfrey includes only the Cypress Hills from this province in the breeding range. However Brazier, Harris and Wedgwood between them found a total of six males and one female. One was within 50 yards of the government cabins where many Society members stayed during the Summer Meet, another was near the Administration Building and others were on the Valley of the Beavers Nature Trail. Considering the limited time available for concentrated search, it could be assumed that more extensive hunting would have easily turned up more of the species, and the Dusky Flycatcher could well be common in the Hills.

While observing the Dusky, I accidentally scared up a second flycatcher. That it hung around in a state of agitation was taken as a sign it was the female near its nest. Also, while it was agitated, the male moved from perch to perch and varied the singing cadence, returning to the original snag and cadence only when I moved to another location. The literature notes that the color of this bird's belly plumage is variable (Godfrey). This was certainly the case with the pair seen. The male's belly was a dirty grey, the female's belly was yellow. The site, a small coulee, was a partially open area in mature mixed woods with 


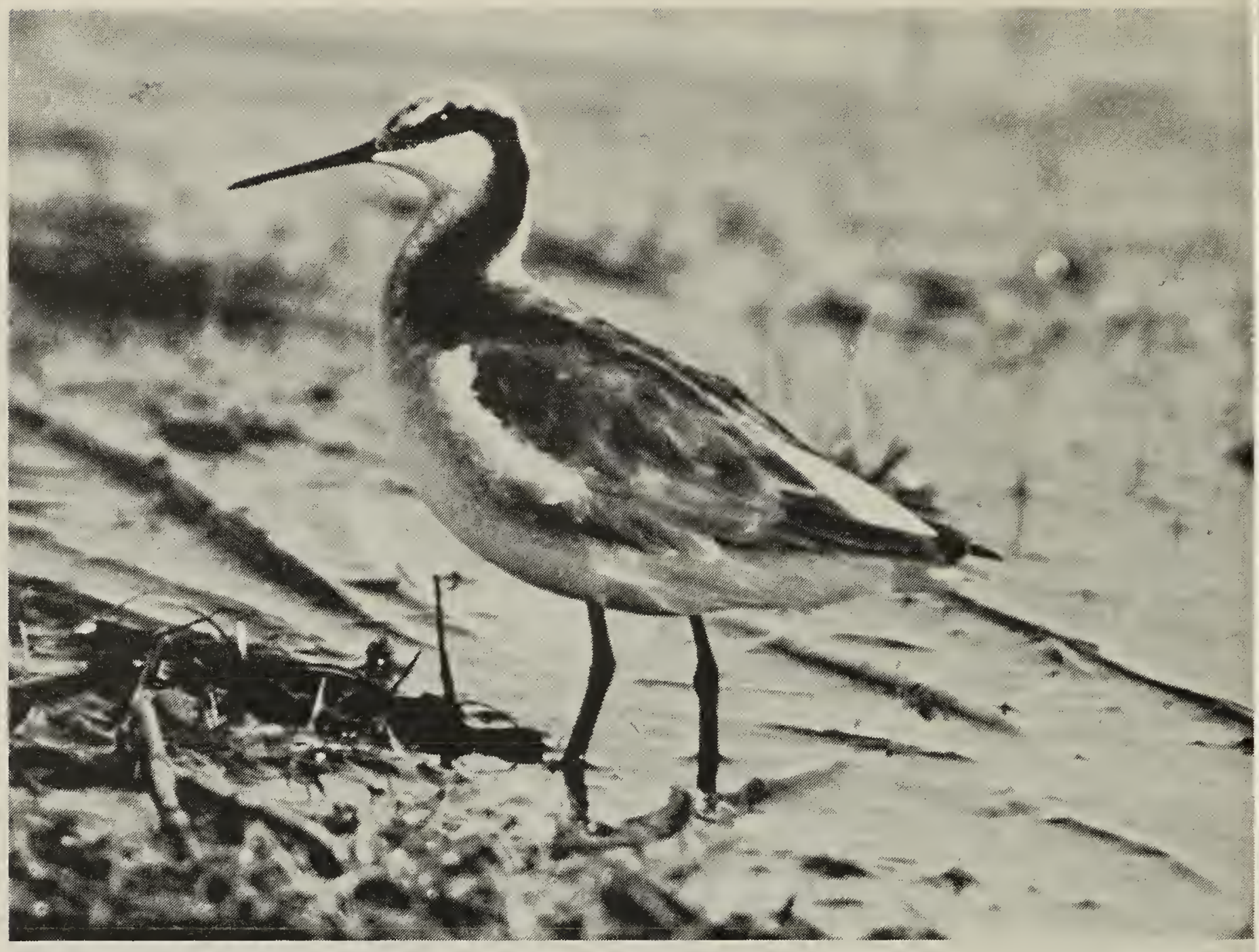

Female Wilson's Phalarope.

Doug Gilroy

much understory brush and some standing dead snags.

Harris saw at least 50 White Pelicans and 500 Double-crested Cormorants on an island in Cypress Lake, a long-time breeding site for these birds. Three Ferruginous Hawks and two pairs of Rough-winged Swallows were also noted in the vicinity.

In the flat country north of the West Block, Nielsen and I saw a Red-tailed Hawk carrying something and being chased by two Long-billed Curlews. As the three birds angled over the adjoining. field, a second pair of curlews joined the chase. A moment later yet another pair rose from a third field over which the hawk was flying. At the same time a single curlew came from a further field and joined the melee. Seven curlews were in the air at once. It is highly likely that if it hadn't been for the hawk we would have driven by without seeing a single curlew, which suggests that the curlew may be more common than one usually imagines.
Other comment: The trip from the Provincial Park in the Centre Block to Fort Walsh in the West Block provided members with a classic illustration of the relation between species and habitat. One drives through three large basic habitat types (plus smaller habitat gradations, edges and local areas): first the coniferous forest of the higher plateau, second the park-like slopes and open areas of the plateau with cinquefoil shrub and aspen, third the mixed grass prairie of the lower rolling land in the gap between the two blocks. A distinct change in birds was obvious as one moved from one region to another. The Oregon Junco (Dark-eyed) and Audubon's Warbler were typical of the forest areas and could be heard "everywhere". The Savannah Sparrow, Least Flycatcher and White-crowned Sparrow were typical birds in the parklands while Sprague's Pipit and Baird's Sparrow were the most frequently heard species in the grassland. All this in addition to the 
wonderful scenery.

The Valley of the Beavers Nature Trail is surely one of the best in the province for variety of birds during the nesting season and especially for species not ordinarily found in Saskatchewan. From one spot it is possible to hear three of the small, difficult-toidentify-by-sight Empidonax flycatchers - Alder, Least and Dusky. At one time one can hear three thrushes - Robin, Veery and Swainson's Thrush - and in a hundred-yard stretch see or hear eight warblers Tennessee, Orange-crowned, Yellowthroat, Redstart, Oven bird, Yellow and the strictly local Audubon's (Yellow-rumped) and MacGillivray's. Throw in nesting White-crowned Sparrows for good measure.

Now available to visitors to the Park is a booklet, The Cypress Hills, a Natural History, written by Helen Morrison of Regina and published by the Saskatchewan Museum of Natural History. It gives an outline of the geological, human and geographic history of the Cypress Hills region, describes the flora and fauna, and includes check lists of the mammals, butterflies, birds and common plants. The bird list is based on Godfrey's Birds of Canada. Such a booklet is a good step forward.

Species Abundance: A total of 110 species were reported in the Cypress Hills district - from Maple Creek south to Cypress Lake and from Highway 21 and Belanger Creek west to the Alberta border. Birds recorded only outside of the Centre and West Blocks and The Gap are designated (d). The coverage was probably sufficient to provide a reasonably reliable impression of abundance for some species. In these instances the notations in the list are: U - Uncommon, less than 5 individuals counted in the 3 days: $C$ - Common, 5-10 individuals; VC - Very common, more than 10 individuals.

Common Loon/U, Horned Grebe/U, White Pelican (d)/VC, Double-crested Cormorant/VC, Great Blue Heron. Trumpeter Swan/U. Canada Goose, Mallard/VC, Gadwall/C, Pintail/C,

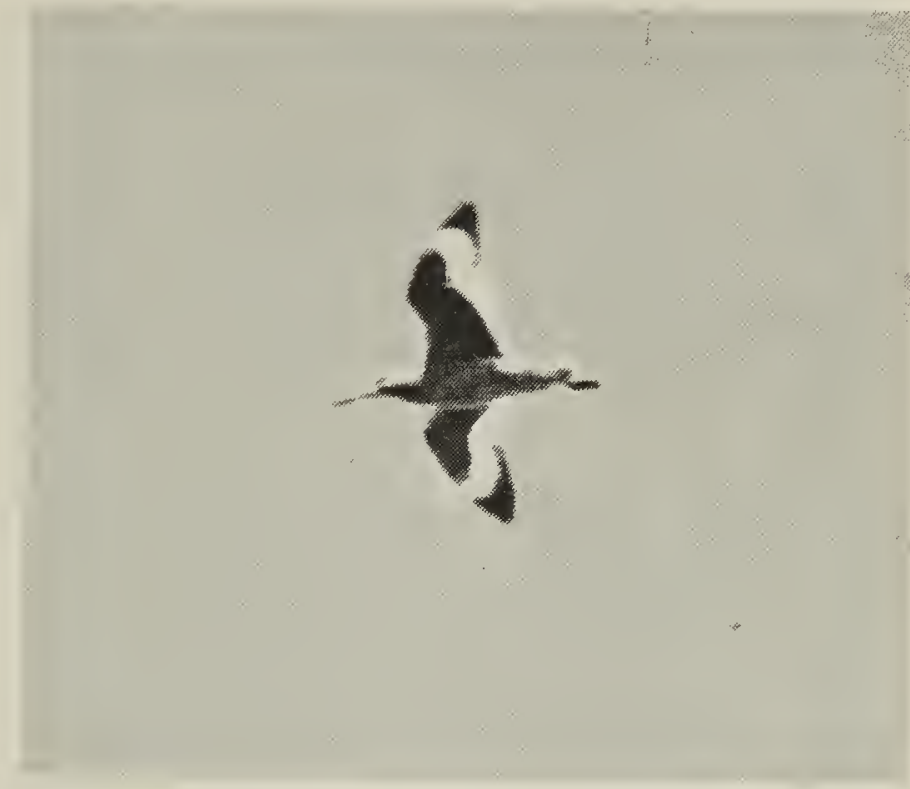

Willet.

Gary Anweiler

Green-winged Teal/U, Blue-winged Teal/VC. American Wigeon/C, Northern Shoveler/C, Lesser Scaup/U, Turkey Vulture, Cooper's Hawk, Redtailed Hawk (d), Broad-winged Hawk, Swainson's Hawk/U, Ferruginous Hawk (d)/U, Golden Eagle/U, Marsh Hawk/U, Ruffed Grouse, Sharptailed Grouse, Ring-necked Pheasant (d), Hungarian Partridge (d), Sora, American Coot/U, Killdeer/VC, Common Snipe/C, Long-billed Curlew (d), Upland Sandpiper/U, Spotted Sandpiper/U, Willet/C, Lesser Yellowlegs, Marbled Godwit/C, Wilson's Phalarope/C, California Gull. Ring-billed Gull/C, Rock Dove (d)/U, Mourning Dove/C, Great Horned Owl, Short-eared Owl (d), Common Nighthawk, Belted Kingfish/U, Yellow. shafted (Common) Flicker/U, Hairy Woodpecker, Yellow-bellied Sapsucker.

Eastern Kingbird/VC, Western Kingbird/U, Alder Flycatcher/U, Least Flycatcher/C, Dusky Flycatcher/C, Western Wood Pewee, Horned Lark/VC, Tree Swallow/U, Bank Swallow/VC, Rough-winged Swallow (d), Barn Swallow/C, Cliff Swallow (d), VC, Purple Martin, Black-billed Magpie/C, Common Crow/C. Black-capped Chickadee/U, Red-breasted Nuthatch/VC. House Wren/U, Robin/VC, Swainson's Thrush/U, Verry/C, Moutain Bluebird/U, Ruby-crowned Kinglet/U, Sprague's Pipit/VC, Cedar Wax. wing/C, Starling. Red-eyed Vireo, Warbling Vireo, Tennessee Warbler, Orange-crowned War. bler, Yellow Warbler/U. Audubon's (Yellowrumped) Warbler/C, Ovenbird/U

MacGillivray's Warbler/VC, Common Yellowthroat/VC, American Redstart/U, House Sparrrow, Bobolink (d). Western Meadowlark/VC, Yellow-head Blackbird, Redwinged Blackbird/VC, Baltimore (Northern) Oriole, Brewer's Blackbird/C. Common Grackle (d) $/ U$, Brown-headed Cowbird/VC. Western Tanager/U, Pine Siskin. American Goldtinch/C. Red Crossbill. Rufous-sided Towhee/C Lark Bunting/VC. Savannah Sparrow/VC, Grasshopper Sparrow (d), Baird's Sparrow/VC. Vesper Sparrow/VC, Oregon (Dark-eyed) Junco/VC. Chipping Sparrow/U, Clay-colored Sparrow/C. White-crowned Sparrow/C. Song Sparrow/C. Chestnut-collared Longspur/VC. 